\title{
OPTIMISING TINE WEEDING IN ORGANIC WHEAT
}

\author{
F. DASTGHEIB

\begin{abstract}
IWM Consultancy, 58 South Belt, Lincoln, Canterbury, New Zealand
Corresponding author: Farhad@inet.net.nz
\end{abstract}

\begin{abstract}
Field trials were undertaken over three years to determine the effect of tine weeding in organic wheat (Triticum aestivum) crops in Canterbury. The tine weeding treatments were performed either as single or repeated passes at different times of crop growth. Pre-emergence tine followed by an early post-emergence tine at the 3-leaf stage gave the highest reduction $(93 \%)$ in weed biomass. However, grain yield of wheat was not significantly affected by tine weeding treatments in any of the experiments. Keywords: cereals, mechanical weed control, organic farming, springtine harrow, weeds.
\end{abstract}

\section{INTRODUCTION}

In organic arable crops in New Zealand, weed control during the season relies mainly on tine weeding with spring-tine harrows. However, the impact of tine weeding on weeds and crops is not well defined. Information about the response of crops and weeds to harrows at different stages of growth can be used to optimise their use for mechanical weed control in organic systems or even as part of integrated weed management in conventional systems.

Very few studies are reported on mechanical weed control in New Zealand. Stiefel \& Popay (1990) studied the effect of tine weeding in cereals. They reported reductions in weed density as much as $80 \%$, without crop damage, from two passes of a tine weeder. Reddiex et al. (2001) compared tine weeder, spoon weeder and inter-row hoe in four crops and found that the performance of these tools depended on the crop. Overseas reports indicate the need for more research on timing and frequency of harrowing for mechanical weed management (Rasmussen 1991; Welsh et al. 1997). Barberi et al. (1999) studied the effect of finger harrowing in durum wheat (T. durum) and found that it only gave comparable yield with chemical control when weed pressure was low.

This study was undertaken to compare different times and numbers of tine weeding in commercially grown organic wheat in central Canterbury. This report follows a previous paper (Dastgheib 2003) and summarises the results from three years of study.

\section{METHODS}

Five experiments were conducted during 2001, 2002 and 2003 on certified organic farms in central Canterbury and received the same crop management applied by the farmers. Details of experimental design, measurements and analysis for 2001 and 2002 are described in Dastgheib (2003). Briefly, both weeds and crop plants were counted in two fixed quadrats $(0.5 \times 0.5 \mathrm{~m})$ per plot, before and one week after each tine weeding. Weed dry matter (DM) was measured approximately one month after the final tine weeding by cutting the plants above the soil surface in two randomly-placed $0.25 \mathrm{~m}^{2}$ quadrats per plot. In 2003, wheat grain yield at maturity was measured by hand, using two randomly placed $2 \mathrm{~m}^{2}$ quadrats per plot. All data were analysed by ANOVA.

In 2003, plot size was $20 \mathrm{~m}$ long and one pass of the tine weeder wide. Tine weeding treatments were designed according to the crop-weed situation as outlined in the Results section. Early post-emergence weeding was conducted at the 2-3 leaf stage and late post-emergence at the 5-leaf stage of wheat. 
In addition to the three experiments in 2001 and 2002 (Dastgheib 2003), two field experiments were conducted in 2003. The first was at Rakaia, using cv. Monad drilled at $130 \mathrm{~kg} / \mathrm{ha}$ on 20 May 2003 on a Templeton silt loam soil following a pea crop. The second experiment was at Aylesbury, using cv. Regency drilled at $135 \mathrm{~kg} / \mathrm{ha}$ on 14 May 2003 on a Lismore silt loam soil following a linseed crop.

\section{Effect of tine on weeds in 2001 and 2002}

\section{RESULTS}

The site of the first year experiment in Rakaia was very weedy with an average of 444 weeds $/ \mathrm{m}^{2}$ in the control plots. Pre-emergence tine weeding alone caused $66 \%$ reduction in weed density, while the combination of pre-emergence + late post-emergence was the most effective treatment giving a reduction of $82 \%$ (Dastgheib 2003). The other two experiments during 2001-02 showed that early post-emergence (2-3 leaf-stage of wheat) tine weeding was more effective in weed control than late (5 leaf stage) post-emergence. Effect of tine on weeds in 2003

At Rakaia, weed infestation was patchy with most weeds in the front portion of plots along a pivot track. The major weed species up to October were chickweed (Stellaria media), fumitory (fumaria officinalis), spurrey (Spergula arvensis), shepherd's purse (Capsella bursa-pastoris) and field pansy (Viola arvensis). Later on fathen (Chenopodium album) became the dominant weed especially along the edges of the field.

On 29 August, weed density was significantly lower (53\%) in plots that had a pre-emergence tine weeding compared to the control plots (Table 1). At the second measurement, early post-emergence and pre-emergence+early post-emergence tine weeding showed significant reductions in weed density. The only treatments with significant reduction from the control at the third measurement were pre-emergence+early post-emergence and pre-emergence+late post-emergence tine. Late post-emergence weeding on its own did not control large weeds, but following a pre-emergence or early post tine, it had some effect, as the weeds were smaller. Measurements of weed biomass in November showed significant reductions by all tine weeding treatments (Table 1), with the greatest reduction of $93 \%$ in plots receiving both pre-emergence and early post-emergence tine weeding.

TABLE 1: Weed density $\left(\right.$ no. $\left./ \mathrm{m}^{2}\right)$ in tine weeding treatments at different assessment dates and weed dry matter $\left(\mathrm{g} / \mathrm{m}^{2}\right)$ measured on $3 / 11 / 03$ in the Rakaia experiment in 2003.

\begin{tabular}{lccccc}
\hline Tine weeding & Date of tine & $29 / 08 / 03$ & $6 / 10 / 03$ & $16 / 10 / 03$ & Weed DM \\
\hline Nil & & 136 & 83 & 97 & 52.4 \\
Pre & $17 / 06 / 03$ & 64 & 68 & 92 & 7.25 \\
Early post & $29 / 08 / 03$ & - & 51 & 84 & 13.3 \\
Late post & $6 / 10 / 03$ & - & - & 88 & 23.1 \\
Pre+Early & & - & 43 & 46 & 3.5 \\
Pre+Late & & - & - & 56 & 9.8 \\
Early+Late & & - & - & 67 & 21.2 \\
\hline LSD $(\mathrm{P}=0.05)$ & & 49.4 & 23.5 & 35.9 & 15.4 \\
\hline
\end{tabular}

At Aylesbury, the major weed species were shepherd's purse, spurrey, mouse-ear chickweed (Cerastium fontanum) and fathen, with annual poa (Poa annua) and clover (Trifolium spp.) also present. Approximately 200 weeds $/ \mathrm{m}^{2}$ were counted in control plots. Early post-emergence tine weeding caused a reduction of $50 \%$ in weed density when measured three weeks after operation (data not shown). Weed density in these plots remained significantly $(\mathrm{P}<0.05)$ lower than the control six weeks after tine weeding. Late post-emergence tine weeding did not result in weed control on its own, but when 
performed on plots with a previous tine weeding, it gave a significant $(\mathrm{P}<0.05)$ reduction of $30 \%$ in weed density.

\section{Growth and yield of wheat crops}

On average, post-emergence tine weeding at 2-3 leaf stage caused between 12 to $18 \%$ mortality in wheat plants, while tine weeding at 5-leaf stage showed only $5 \%$ crop mortality. Grain yield data from four experiments presented in Table 2 showed no significant differences between treatments. Grain yield in Dunsandel was extremely low due to poor establishment of the crop and invasion of perennial weeds later in the season. The site in Aylesbury was rainfed and serious drought conditions in the summer of 2003 resulted in low yields. In 2003, at Rakaia, there was a yield increase of $1.7 \mathrm{t} / \mathrm{ha}$ in pre-emergence+early post-emergence tine compared to the control, but this was not statistically significant due to variability in data.

TABLE 2: Wheat grain yield ( $t /$ ha) for tine weeding treatments in four field experiments.

\begin{tabular}{lcccc}
\hline Tine weeding & $\begin{array}{c}\text { Rakaia } \\
2001^{1}\end{array}$ & $\begin{array}{c}\text { Dunsandel } \\
2002\end{array}$ & $\begin{array}{c}\text { Aylesbury } \\
2003\end{array}$ & $\begin{array}{c}\text { Rakaia } \\
2003\end{array}$ \\
\hline Nil & 4.23 & 1.41 & 2.45 & 5.25 \\
Pre-emergence & 4.39 & - & - & 5.87 \\
Early post & 4.49 & 1.59 & 2.85 & 5.42 \\
Late post & 4.27 & 1.27 & 2.55 & 5.54 \\
Pre+Early & - & - & - & 6.99 \\
Pre+Late & 4.36 & - & - & 6.48 \\
Early+Late & - & 1.83 & 2.51 & 4.83 \\
\hline LSD $(\mathrm{P}=0.05)$ & $\mathrm{ns}$ & $\mathrm{ns}$ & $\mathrm{ns}$ & $\mathrm{ns}$ \\
\hline
\end{tabular}

${ }^{1}$ From Dastgheib (2003).

\section{DISCUSSION}

The results over three years showed that early passes of tine weeding control weeds better than late passes but also cause more crop damage. To compensate for the loss, a higher sowing rate than recommended for conventional crops should be considered. However, a good wheat crop is able to tolerate some loss without yield penalty. The trials in 2002-03 clearly demonstrated the importance of crop vigour in weed suppression when two contrasting situations were compared (Dastgheib 2003). A sound weed management strategy should, therefore, include practices for best crop husbandry to encourage crop growth and development.

Pre-emergence tine weeding at Rakaia gave $53 \%$ reduction in weed density as measured early in the season (Table 1), but new flushes of weeds appeared in these plots. When a pre-emergence tine was followed by an early post-emergence tine at the 3-leaf stage, the low weed density was maintained throughout the season. This treatment also gave the highest reduction (93\%) in weed biomass when measured towards the end of the season.

There were significant increases in wheat growth due to early tine weeding when measured in mid-season (Dastgheib 2003). However, the results from all experiments indicate that in most cases tine weeding does not improve grain yield (Table 2). This is mainly due to the excellent ability of wheat to compete with annual weeds once the canopy closure starts. In contrast to wheat, peas showed significant yield response to tine weeding treatments (Dastgheib 2004). Previously, Stiefel \& Popay (1990) and Welsh et al. (1997) reported no yield increases in wheat following one or two passes of tine weeding. Further, an analysis of 59 wheat crops in Canterbury revealed that (chemical) weed control was likely to be uneconomic in $24 \%$ of the fields (Bourdôt et al. 1996). Nevertheless, a statistically non-significant increase of $1.7 \mathrm{t} / \mathrm{ha}$ in grain yield achieved in Rakaia in 2003, by two passes of tine weeding at pre-emergence+early post-emergence indicates a promising treatment. 


\section{ACKNOWLEDGEMENTS}

The project was jointly funded by Agricultural and Marketing Research and Development Trust (AGMARDT), Foundation for Arable Research (FAR) and Heinz Wattie's. The author wishes to thank Andrew Brooker, John and Kelvin Hicks, and Philip Rushton for providing sites and machinery for the experiments.

\section{REFERENCES}

Barberi, P., Silvestri, N., Perruzi, A.; Rafaelli, M. 1999: Finger harrowing of durum wheat under different tillage systems. Biol. Agric. Hort. 17 (4): 285-303.

Bourdôt, G.W., Saville, D.J., Hurrell, G.A.; Daly, M.J. 1996: Modelling the economics of herbicide treatment in wheat and barley using data on prevented grain yield losses. Weed Res. 36: 449-460.

Dastgheib, F. 2003: Timing and frequency of tine weeding in organic wheat and pea crops. Proc. Agron. Soc. N. Z. 33: 43-49.

Dastgheib, F. 2004: Optimising tine weeding in organic pea crops. N. Z. Plant Prot. 57: 45-48.

Rasmussen, J. 1991: Optimising the intensity of harrowing for mechanical weed control in winter wheat. Brighton Crop Prot. Conf. - Weeds: 177-184.

Reddiex, S.J.; Wratten, S.D.; Hill, G.D.; Bourdôt, G.W.; Frampton, C.M. 2001: Evaluation of mechanical weed management techniques on weed and crop populations. N. Z. Plant Prot. 54: 174-178.

Stiefel, W.; Popay, A.I. 1990: Weed control in organic arable crops. Proc. 43rd N. Z. Weed and Pest Control Conf.: 138-141.

Welsh, J.P., Bulson, H.A.J., Stopes, C.E., Froud-Williams, R.J.; Murdoch, A.J. 1997: Mechanical weed control in organic winter wheat. Aspects Appl. Biol. 50: 375384. 